consequence of these two transformations of the food system. Global trade is able to supply progressively cheaper food, at high cost to humans and the environment, yet there is a paradox of plenty amidst widespread hunger. Food-borne diseases resulting from modern farming techniques for livestock have also sharply raised the probability of an uncontrollable pandemic.

Roberts is not hopeful of a solution to these problems because of the economic forces that dominate. He avoids conspiracy theories, but distrusts the coordination between the producers and consumers that is central to the capitalist system. He is not alone. To paraphrase British prime minister Winston Churchill on democracy, capitalism is the worst way to organize society's economic activities, except for all of the alternatives. Communist Cuba, for example, returned to a system of local food production using human and animal power to produce a nutritionally adequate diet. Roberts accepts this is hardly a good global solution.

There are two approaches to making our food system safer and more sustainable, yet still accessible to the world's population, which is expected to increase by two billion during the next $30-50$ years. Both strategies should be pursued simultaneously.

First, and ironically in view of Roberts's critique, the global capitalist system needs to be harnessed to help solve problems of food scarcity, pricing and inequity. Fortunately, it is already moving in the right direction. The rising cost of energy makes many elements of the food industry unprofitable. High fertilizer prices, high transportation costs and high meat prices all push the system towards less intensive, locally produced and healthier alternatives.

Second, good public policy and government investments in food and agricultural research can make a big difference. Moreeffective regulation, better-educated consumers and healthier school environments can all follow from elected officials who care about the quality and quantity of the food they and their families eat.

The End of Food is a call to arms. But there will be no revolution. We will all be buried in our oversized coffins before a radical solution comes, because change will be gradual. So we must get on and fix the system we have.

C. Peter Timmer is a visiting professor in the Program on Food Security and the Environment, Stanford University, Stanford, California 94305, USA, and author of $A$ World Without Agriculture: The Structural Transformation in Historical Perspective.

\title{
Horse power unbridled
}

The Horse
American Museum of Natural History,
New York
Until 4 January 2009.

Noble, speedy, dependable and strong, the horse changed the course of human history. The domestication of Equus caballus some 6,000 years ago supplied people with a reliable year-round source of food, enabling them to settle in villages and ride to communities farther afield. Horses have since helped humans plough fields, carry supplies, haul water, mine coal, fight battles and conquer continents. The animals raced through the earliest art and have a renowned place in religion and sport.

They also inspired the invention of trousers. As explained in The Horse, an exhibition at the American Museum of Natural History in New York, trousers were designed for the comfort of riders, and only later adapted for more general use. They appear on a fifth-century BC urn from southern Italy that depicts a duel between an Amazon woman and a Greek warrior. Mounted on a horse and clothed in striped Persian pantaloons, the Amazon aims her spear at the Greek, who fights back helplessly on foot. The exhibition emphasizes that humans owe more to horses than practical fashion; curator Ross MacPhee calls the animals "the first multipurpose engines, animated machines".

Horses helped power the Industrial Revolution: they hauled goods from steamships or trains to warehouses and markets. Horses often worked in tandem with machines; by the 1870 s, more than 300 US patents had been issued for horse-powered machinery. One horse-drawn contraption on display is a threemetre-long, three-tonne steam fire engine made of iron and steel, dating to 1896. Before the mid-nineteenth century, men pulled and hand-pumped fire engines. A draft horse is strong enough to lift 150 kilograms a distance of 30 metres in one minute, or, as Scottish inventor James Watt calculated in the $1770 \mathrm{~s}$, 33,000 'foot-pounds' per minute, a quantity he defined as one horsepower. Museum visitors can pull down a lever and measure their own strength: after some practice and puffing, and by using both hands, I scored about a fifth of one horsepower.

The great mobility of horses derives in part from their ability to graze and digest grass on the go, enabling them to walk all day. Their speed hails partly from their single hooves, which evolved around 12 million years ago in a genus called Pliohippus, relatives of modern-day Equus - single hooves enabled

them to run farther and faster than their three-toed, forest-dwelling ancestors. These adaptations helped the cavalries of Genghis Khan and his descendants to conquer most of Asia, the Middle East and Russia. Mongol horsemen did more than pillage: they spread innovations along the Silk Road such as the bow fiddle, which originated in central Asia around 1,000 years ago and had a bow strung with horsetail hair. A modern Mongolian example of the morin khuur, the horsehead fiddle, is on display, as are other forms of horse-inspired art: reproductions of 32,000-year-old paintings of horses
A brass toy horse and oldier from India. galloping gracefully along the walls of the Chauvet cave in France; children's toy horses; and a garland-trimmed, 2-metre-long terracotta horse from Tamil Nadu, India, created as an offering to local gods.

A powerful bond exists between humans and horses. A film exhibit shows an organization called GALLOP, based in Brooklyn, New York, which provides therapeutic horseback rides for people with disabilities. In one segment, Sarah Lisker, a girl who has cerebral palsy, is lifted from her wheelchair onto a horse and parades around confidently, assisted by an instructor. "What did the horse teach you?" the instructor asks. "That I'm his friend," Sarah replies, and then murmurs, "Trot on."

Josie Glausiusz is a journalist based in New York. 